\title{
Drowning of the Miocene Billund delta, Jylland: land-sea fluctuations during a global warming event
}

\author{
Erik Skovbjerg Rasmussen, Torsten Utescher and Karen Dybkjær
}

Lower Miocene strata from boreholes and, in particular, at outcrops in the Lillebælt and Limfjorden areas of Jylland provide a natural laboratory for studying the drowning of a major delta system during a period of global warming. Detailed studies of sedimentary structures, fossil algae, spores and pollen give information about depositional environments, local temperatures and precipitation. By comparing with the global climatic record from the same period, a detailed reconstruction of the flooding of a low-relief delta system can be made, with emphasis on the global warming after the glacial event Mila. The local temperature increase following the Mila event is estimated to be $c .5^{\circ} \mathrm{C}$.

\section{The Billund delta}

During the Early Miocene, a delta system prograded into the eastern part of the North Sea (Fig. 1), with a sediment source in present-day Norway and central Sweden. For more than 100 million years, the eastern North Sea was a relatively deep basin, but due to tectonism associated with the Alpine Orogeny and the opening of the North Atlantic both the hinterland and the marginal areas of the basin were uplifted during the latest Oligocene - Early Miocene (e.g. Knox et al. 2010). Inversion tectonism in the Norwegian-Danish Basin resulted in shallower water depths of $c .100 \mathrm{~m}$ in the eastern North Sea. Contemporaneous uplift of the Norwegian mountains provided a high sediment supply sourcing a major delta system prograding southwards into the North Sea region. The delta front was shaped by wave action, similar to the present-day Nile and Danube deltas (Bhattacharya \& Giosan 2003), with a size comparable to the latter. Spit and barrier systems formed east of the main delta lobes (Fig. 1) due to the prevailing westerly winds in the North Sea area at that time. From the geological record, it is seen that the delta system prograded as far south as present-day southern Jylland (Fig. 1A).

\section{Drowning of the land}

The depositional environments of the Billund delta system are reconstructed from sedimentological studies (Figs 1, 2). During the maximum extent of the delta, most of present-day Jyl-
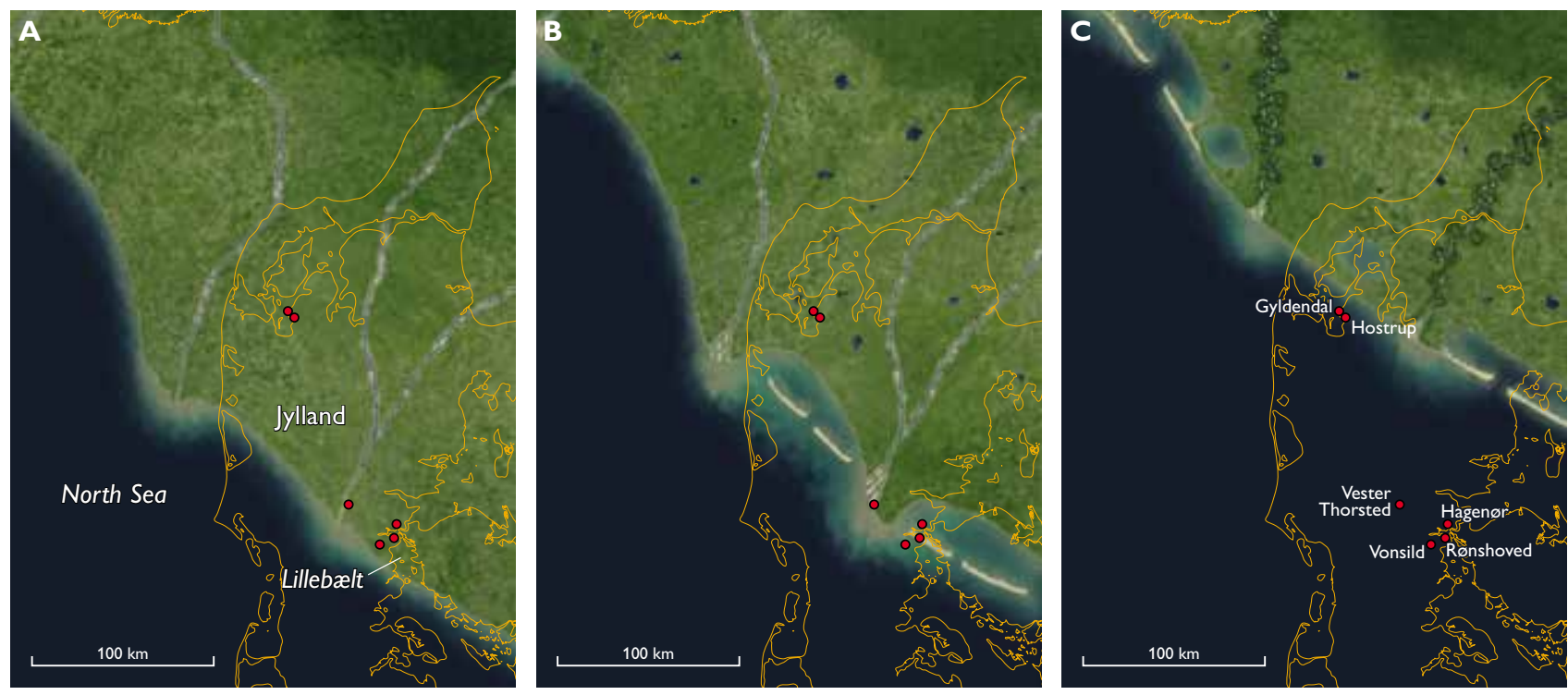

Fig. 1. Palaeogeographic reconstruction of the Early Miocene in the eastern part of the North Sea basin. A: Billund Formation during maximum regression. B: Klintinghoved Formation during initial transgression (Kolding Fjord Member). C: Klintinghoved Formation during maximum transgression. Modifided from Rasmussen et al. 2010. 


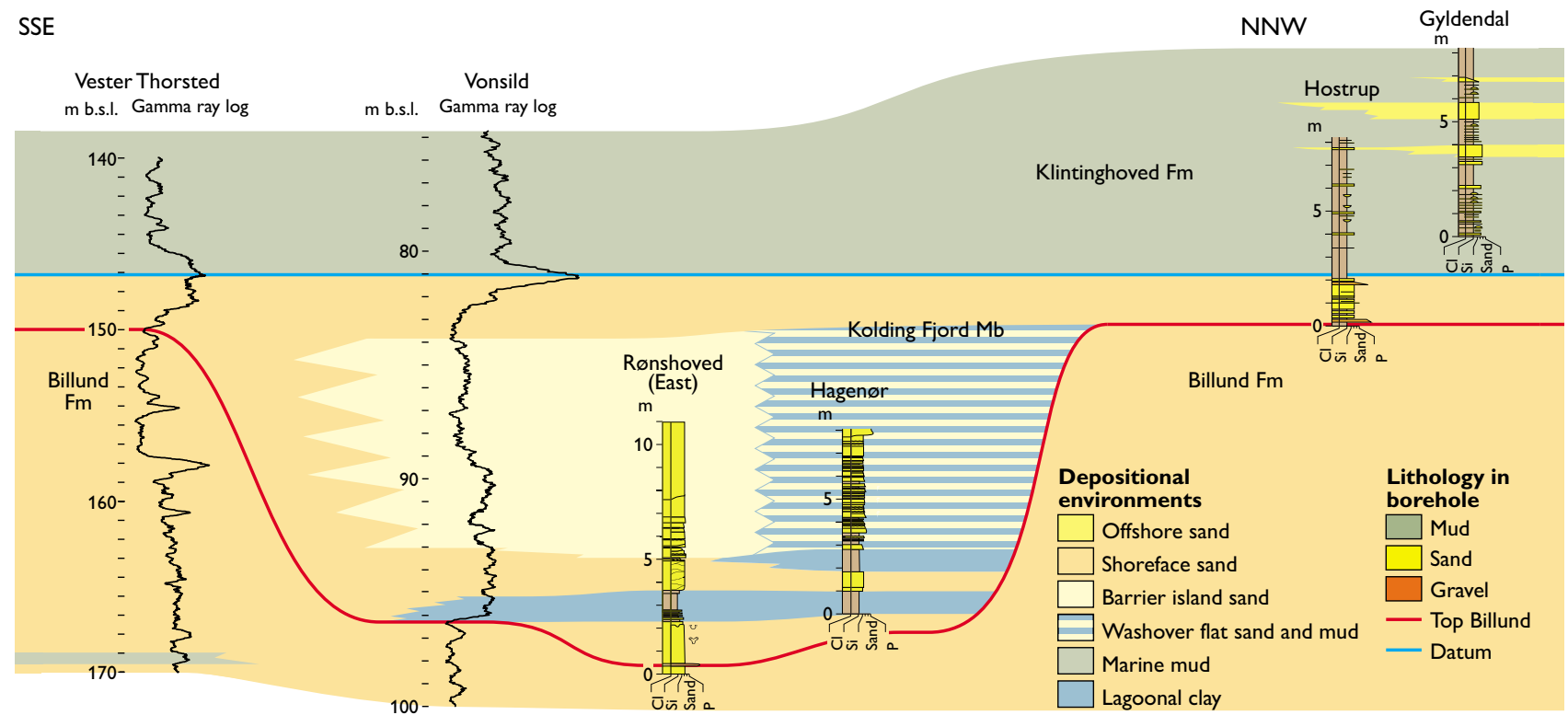

Fig. 2. Correlation panel of the Lillebælt area and Limfjorden.

land was covered by braided fluvial channels and flood-plain environments (Fig. 1A). In the late stage of delta progradation, the delta plain was irregular due to topographic elements formed associated with falling sea level, i.e. down-stepping delta platforms and incisions, and due to minor inversion of the basin (e.g. Rasmussen et al. 2010).

During later flooding, most of the deposits were redistributed by the action of waves. Mud and fine-grained sand were winnowed away and transported into the deeper sea, whereas coarse-grained sand and gravel were reworked and redeposited locally. Therefore, a widespread lag of gravel caps the shoreface sand of the underlying Billund Formation (Fig. $3 \mathrm{~A}, \mathrm{C}$ ). Intense wave action on the main delta system shed sand towards the east, resulting in the formation of spit and barrier systems in eastern Jylland (Fig. 1B); lagoons and tidal flats developed north of these systems. Both shoreface and lagoonal deposits accumulated in a depositional setting dominated by waves. The shoreface sand is dominated by hummocky and swaley, cross-stratified sand, and the lagoonal mud is commonly intercalated with washover fans (Fig. 3B).

From the sedimentary record, it is seen that the initial drowning of the Billund delta system was characterised by flooding and re-establishment of land in two phases (Fig. 2), which only influenced the distal part (tens of kilometres) of the delta plain. Transgressive deposits up to $15 \mathrm{~m}$ thick are found at localities around Lillebælt, Rønshoved and Hagenør (Fig. 2). At Hagenør, two stacked lagoonal mud units separated by shoreface sand show that relatively stable barrier systems were established twice during the transgression (Figs 2, 3B). During the main flooding, the low-relief delta plain (similar present-day delta systems have gradients of $c .1 / 20000$ ) was flooded relatively quickly, and only up to $c .1 \mathrm{~m}$ of transgressive sediments were deposited, e.g. at Hostrup (Figs 2, 3C). At this locality, the relatively rapid changes in depositional environment during the main transgression are seen from the coexistence of the marine trace fossil Ophiomorpha and rootlets (Schaubcylendrichnus; Fig. 3C).

From studies of global sea-level changes in the Early Miocene, it appears that sea-level variations in the order of $25 \mathrm{~m}$ occurred during the Mila event (Miller et al. 2005). This change in sea level resulted in rapid progradation during the sea-level fall. The succeeding flooding can be followed for $c$. $75 \mathrm{~km}$ towards the north-east in the Danish area (Fig. 1C). Maximum flooding has not been documented at any outcrop in Denmark, but the sedimentary succession at Hostrup indicates that the shoreline was located not far from this locality at any time because the marine mud of the Klintinghoved Formation is strongly influenced by terrestrial matter throughout the section. Most of the $25 \mathrm{~m}$ of sea-level change must be explained by the $15 \mathrm{~m}$ transgressive deposits found at Rønshoved and Hagenør (compaction can be ignored in sorted shoreface sand) in the southern part of the delta system where some relief was created during the sea-level fall and lowstand. Additional $5 \mathrm{~m}$ of relief of the main delta calculated from $75 \mathrm{~km}$ of flooding gives a total of $20 \mathrm{~m}$ of transgressive deposits. As the sea-level changes were in the order of $25 \mathrm{~m}$ (Miller et al. 2005), the remaining $5 \mathrm{~m}$ can be ascribed to more or less stable conditions for a period (aggradation of the system) or waning of the inversion tectonism. In the upper part of the Hostrup and Gyldendal sections, the 

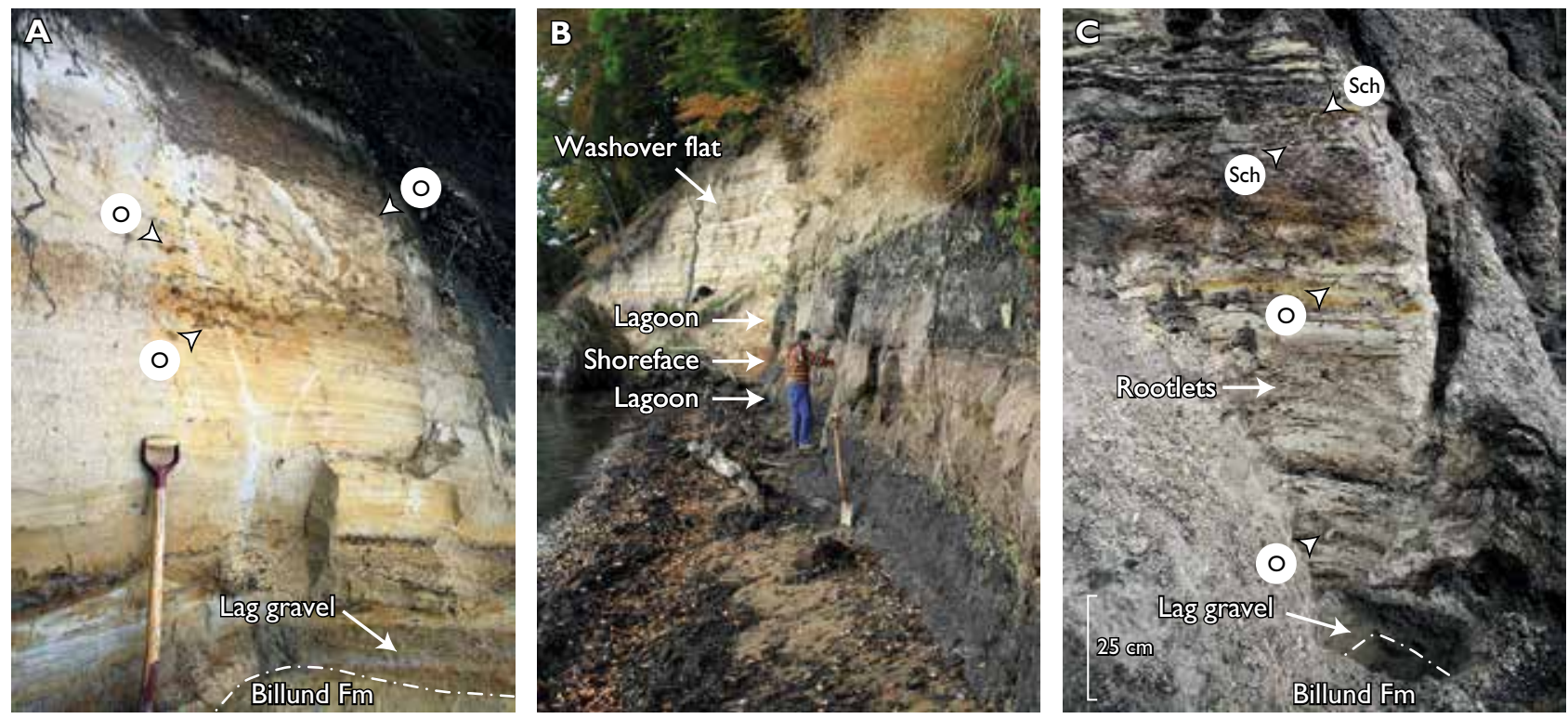

Fig. 3. Photographs of lithologies of the outcrops of the Billund and Klintinghoved Formations. A: Shoreface deposits from Rønshoved. Note the gravel layer, the base of which forms the lower part of the Klintinghoved Formation. B: Lagoonal deposits from Hagenør. Note that sand-rich washover fans dominate the upper part. C: Transgressive sand and marine mud of the Klintinghoved Formation at Hostrup. The lag of gravel at the base of the Klintinghoved Formation is seen in the lower part of the photograph. Both rootlets and marine trace fossils are found in the sand-rich deposits. O: Ophiomorpha, Sch: Schaubcylindrichnus (rootlets).

increased intercalation of hummocky, cross-stratified sand layers indicates resumed progradation of the shoreline.

\section{Climate and vegetation change}

Changes in continental climate and vegetation in the study area around the Mila glacial event and the subsequent drowning of the Billund delta system were reconstructed from pollen and spores (Fig. 4). Although terrestrial signals are commonly diluted in marine strata due to transport and reworking, our data show close correlation with the evolution recorded in the marine part. Climate reconstruction using the 'Coexistence Approach' of Mosbrugger \& Utescher (1997) shows distinct cooling during the formation of the Billund delta and the sea- level lowstand that culminated at $c .164 \mathrm{~m}$ in the Vester Thorsted well (Fig. 4). This is followed by warming that coincides with sea-level rise and drowning of the delta system. The cooling event is characterised by declining winter temperatures, with a fall of $c .5^{\circ} \mathrm{C}$ mean temperature in the coldest month. Summer temperatures were stable to begin with, but later increased during progressive transgression (Hagenør sample). The palynomorph record points to humid conditions with over $1000 \mathrm{~mm}$ annual rainfall over the time span analysed. The precipitation was not equally distributed throughout the year but showed distinct seasonality (cf. monthly precipitation records, Fig. 4). The monthly means indicate that cooling was accompanied by declining precipitation during the wettest season and hence to a lesser degree of seasonal rainfall.
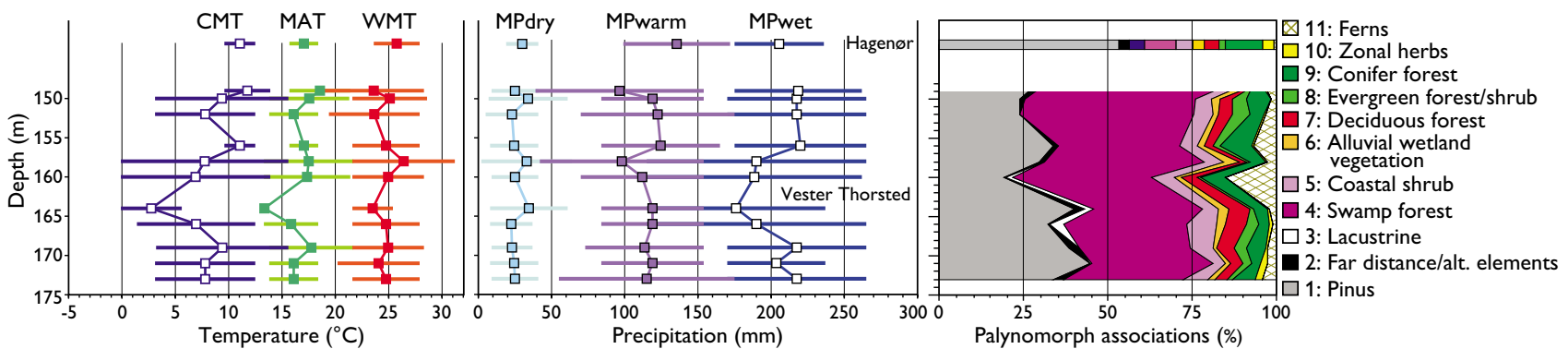

Fig. 4. Climate records and synthesised pollen diagram for depth range 149-173 m of Vester Thorsted borehole. Results obtained from lagoonal silts deposited in the trangressive phase of sequence $\mathrm{C}$ are shown on top. The lagoonal silts were sampled in the nearby Hagenør outcrop. CMT: Cold month mean, MAT: Mean annual temperature, WMT: warm month mean, MPdry, MPwarm, MPwet: Mean precipitation of the driest, warmest and wettest month. 
In the warmer climate reconstructed higher up in the transgressive systems track (sample Hagenør), the region received more precipitation in the warm season.

The palynomorph record also allows us to follow the evolution of continental ecosystems triggered by climate and sea-level change. The synthesised pollen diagram (Fig. 4) shows frequency variations of groups reflecting regional to local biomes. Pollen groups 1 and 2 comprise the pine family that includes many prolific pollen producers. Association 1 mainly comprises pine, but in the Hagenør sample small percentages of cedar and Cathaya are also seen. The latter, monotypic genus occurs today as an endemic relict in central China. Other members of Pinaceae such as Abies, Picea and Larix (group 2), frequently referred to vegetation of higher altitudes, are not important in the spectra $(<3.5 \%)$. Pine pollen can be dispersed over long distances and are relatively enriched in open marine palynomorph spectra (e.g. Larsson et al. 2011). The overall declining trend of pine pollen recorded in the Vester Thorsted samples (from $45 \%$ at the base to $25 \%$ at $160 \mathrm{~m}$ ) traces the falling sea-level and increased terrigenous input during the formation of the delta. The high pine pollen value for Hagenør $(>50 \%)$ coincides with the rising sea-level of the transgressive phase. Lacustrine group 3, comprising lacustrine plankton, pteridophyte and angiosperm limnophytes, reaches its highest values (c. 5\%) during the cooling event (at $164 \mathrm{~m}$ ) and probably marks the most proximal conditions, together with fern group 11 that is frequent at the levels immediately above. These components originate from the local vegetation found on unstable, alluvial deposits on the delta plain. Two groups of palynomorphs $(4+5)$ that probably represent the vegetation of coastal swamps attain very high proportions during delta formation and show a distinct increase from c. 40 to over 55\% which allows us to trace the ongoing regression. Low values at Hagenør (c. 10\%) indicate that coastal swamps drowned as sea level rose. The arboreal vegetation on the coastal swamps comprises taxodioids (Taxodium, Sciadopitys and other Cupressaceae), with Ericaceae and Myricaceae representing the shrub layer. Pollen from alluvial wetland vegetation (6) play a minor role in the spectra and indicate a lack of widespread riverine forests, whereas palynomorphs usually assigned to zonal vegetation (groups 7-10) are present with 10 to $15 \%$ as permanent background. The zonal vegetation was a diverse, mixed conifer / broadleaved forest with evergreen and deciduous oak, magnolia, chestnut, sweetgum, members of Juglandaceae, hemlock, coast redwood and palms. It is noteworthy that climate changes recorded in the section affected its generic composition. During the cool phase, between 156 and $164 \mathrm{~m}$, the forest almost completely lost its broadleaved evergreen species, and thus had a more temperate aspect.

\section{Concluding remarks}

During a global warming in the Early Miocene when the local temperature increased by $5^{\circ} \mathrm{C}$, the Billund delta system was flooded. The displacement of the shoreline was in the order of $75 \mathrm{~km}$ and affected the coastal vegetation. Up to $15 \mathrm{~m}$ of alternating lagoonal and shoreface deposits were formed in the distal portion of the delta evidencing some stability in the early phase due to antecedent relief and high sediment supply. The main low-relief delta plain was, however, flooded quickly and only left $c .1 \mathrm{~m}$ of transgressive deposits. Yearly precipitation rates were in the order of $1000 \mathrm{~mm}$; the warming was accompanied by changes in seasonal patterns of rainfall so that during warmer periods there is a tendency to more summer rain.

\section{Acknowledgements}

The Nature Agency centres in Ribe, Ringkøbing and Aarhus are thanked for financial support. T.U. thanks the German Science Foundation (DFG) for finacial support.

\section{References}

Bhattacharya, J.P. \& Giosan, L. 2003: Wave-influenced deltas: geomorphological implications for facies reconstruction. Sedimentology $\mathbf{5 0}$, 187-210.

Knox, R. et al. 2010: Cenozoic. In: Doornenbal, J.C. \& Stevenson, A.G. (eds): Petroleum geological atlas of the southern Permian Basin area, 210-223. Houten, the Netherlands: European Association of Geoscientists \& Engineers (EAGE) Publications.

Larsson, L.M., Dybkjær, K., Rasmussen, E.S., Piasecki, S., Utescher, T. \& Vajda, V. 2011: Miocene climate evolution of northern Europe: a palynological investigation from Denmark. Palaeogeography, Palaeoclimatology, Palaeoecology 309, 161-175.

Miller, KG., Kominz, M.A., Browing, J.V., Wright, J.D., Mountain, G.S., Katz, M.E., Sugarman, P.J., Cramer, B.S., Christie-Blick, N. \& Pekar, S.F. 2005: The Phanerozoic record of global sea-level changes. Science 310, 1293-1298.

Mosbrugger, V. \& Utescher, T. 1997: The coexistence approach: a method for quantitative reconstructions of Tertiary terrestrial palaeoclimate data using plant fossils. Palaeogeography, Palaeoclimatology, Palaeoecology 134, 61-86.

Rasmussen, E.S., Dybkjær, K. \& Piasecki, S. 2010: Lithostratigraphy of the upper Oligocene - Miocene succession in Denmark. Geological Survey of Denmark and Greenland Bulletin 22,93 pp.

\section{Authors' addresses}

E.S.R. \& K.D., Geological Survey of Denmark and Greenland, ØsterVoldgade 10,DK-1350 Copenhagen K, Denmark. E-mail: esr@geus.dk

T.U., Steinmann Institute, University of Bonn, Nußallee 8, 53115 Bonn; Senckenberg Research Institute / BiK F, Senckenberganlage 25, 60325 Frankfurt/ Main, Germany. 